\title{
The African Commission on Human and Peoples' Rights as a Collective Human Security Resource: Promise, Performance and Prospects
}

Obiora Chinedu Okafor

Osgoode Hall Law School of York University, ookafor@osgoode.yorku.ca

\section{Source Publication:}

Protecting Human Security in Africa. Oxford, UK: Oxford University Press, 2010.

Follow this and additional works at: https://digitalcommons.osgoode.yorku.ca/scholarly_works

\section{Repository Citation}

Okafor, Obiora Chinedu, "The African Commission on Human and Peoples' Rights as a Collective Human Security Resource: Promise, Performance and Prospects" (2010). Articles \& Book Chapters. 226. https://digitalcommons.osgoode.yorku.ca/scholarly_works/226 


\section{The African Commission on Human and Peoples' Rights as a Collective Human Security Resource: Promise, Performance, and Prospects Obiora Chinedu Okafor}

DOI:10.1093/acprof:oso/9780199578986.003.0013

\section{Abstract and Keywords}

This chapter argues that contrary to the way in which it has been generally imagined in the dominant collective human security literature, the African Commission is by design, and in terms of its institutional practice, an important collective human security resource in Africa. Section 2 of this chapter provides a short background on the African Commission. Section 3 discusses the normative and textual promise that the African Commission shall, through the effective discharge of its broad human rights mandate, serve as an important collective human security resource. Section 4 then systematically considers the institutional practice of the African Commission in this regard, and reaches analytical conclusions as to the quality of its performance. Section 5 examines the African Commission's prospects as a collective human security resource, and makes some recommendations as to what needs to be done to enhance its utility and significance as such a resource. Section 6 summarizes and concludes the chapter.

Keywords: African Commission, human rights, human security, background, human rights mandate

\section{Introduction}

It is almost trite these days to state that the attainment and maintenance of peace and security depends, to a highly significant degree, on the enjoyment within the target population of a broad range of human rights, including economic, social, and cultural rights. The scholarly and institutional literature is now replete with evidence and arguments that justify such a conclusion. 1 Indeed, one commentator (p.314) has recently gone as far as arguing that the intimate connection between peace and security, on the one hand, and respect for human rights, on the other hand, has long been recognized across civilizations that were as different as 6th Century China and the USA of the 1960s. 2 Yet, until more recently, within the dominant literature sets and in the prevalent institutional praxis, the concept of collective security has not been traditionally linked in as close or positive a manner with the enjoyment of human rights. By contrast, as fluid and organic a concept as it has been, 3 the collective security concept has been historically captive to and mostly discussed in terms of international action to constrain the use or threat of the use of military force by one state against another: the multilateral prevention or stoppage of the inappropriate uses of military violence across state borders. 4 As Anne-Marie Slaughter has stated:in 1945, when the founders of the U.N. talked about...the security council as a whole being responsible for international peace and security [that is Collective human security], they were talking about state security. They were not [for the most part] worried about what would happen if a government or [some within] one ethnic group decided to massacre hundreds of thousands of fellow citizens. They worried about what happened if one state invaded another. 5

Leon Gordenker and Thomas G Weiss underline the deep-rooted position of this traditional conception of collective human security as well as its seemingly enduring quality when they declare that:

the central idea [of collective security] has remained the same: the governments of all states would join together to prevent any of their number from using coercion to gain advantage, especially conquering another. Thus, [within this kind of arrangement] no government could with impunity undertake forceful policies that would fundamentally disturb peace and security. $\underline{6}$ 
However, Tom Farer has offered a characteristically insightful definition of collective security that captures its enduring commitment to the traditional overly state-centred conception of security as the avoidance of the use or threat of military force, while being flexible enough to reflect the changing conception of that expression. To Farer, a collective (human) security arrangement is 'a collective (p.315) institutionalized commitment...to gang up on any state that acts in defiance of collective judgments about permissible behavior'. 7

Yet, as flexible as Farer's definition seems, the traditional conception of collective human security has also suffered from the very same deficiencies as the historically dominant military/state-centred conception of one of its key terms (that is, security). As a result of a long period of increasingly intense contestation over its continued accuracy, utility, and relevance, $\underline{\underline{s}}$ the traditional security conception and framework eventually proved unable to accommodate and cope with many of the emergent security-related pressures of our time, including such challenges as environmental degradation, mass international migration, and certain mass human rights violations. ${ }^{9}$

Only more recently has a different conception of security gained currency in the relevant literature; one that promises to re-orient substantially the collective human security idea. This emergent concept is represented by the term 'human security'. Currently much-discussed, this concept has emerged as a result of the felt academic and institutional need to 'fashion a new and broader understanding...of what [security, and thus] Collective human security means'; 10 one that would expand that concept well beyond its historically near-exclusive focus on the use of military force and on the state.11 As MacFarlane and Khong have noted:

the discussion of security has expanded horizontally beyond military issues to take into account others, such as the economy, the environment, health, gender, and culture, in the context of an expansion of core values to include welfare and identity. It has also expanded vertically, questioning the rationale for exclusive focus on the state and suggesting that security might have other referent subjects.12

Thus, as Slaughter has correctly noted, from the perspective of the human security concept, it does not matter whether one dies from a bullet or from AIDS or hunger; what matters is that one dies. 13 First popularized in the early 1990 os by the United Nations Development Program (UNDP), 14 the arrival of this newer concept signals a concerted and necessary attempt to link security discourse much more closely to 'conditions of (p.316) existence and immediate vulnerability'.15 As Fukuda-Parr has argued, the broad goal of security is, and should be, to enable people to live without fears for their survival, well-being, and freedom-hence the emergence of the term 'human security'.16 What is more, this new approach is much more in keeping with the sense in which the vast majority of the world's peoples experience and think about security. 17

This does not mean, however, that the human security concept is susceptible to easy definition. Indeed, one commentator has been able to document approximately 25 definitions of human security..$\underline{18}$ Although there is really no compulsion to dwell on the question of the definition of this concept in a chapter such as this (which does not focus on the nature of human security concept per se), it is necessary nevertheless to adopt a working definition of the concept. As it is used in this chapter, and as also noted in Chapter $\underline{1}$ of this volume, the term 'human security' means:

the security of people-their physical safety, their economic and social well-being, respect for their dignity and worth as human beings, and the protection of their human rights and fundamental freedoms. 19 
Focused as it is on 'the individual as the principal referent of security'o the human security idea reconceptualizes security (and thus collective human security) no longer in terms of state security exclusively, but rather in terms of human needs. $\underline{21}$ For, the interests of a people are not always coterminous with the interests of the state of which they are a part. At the core of this newer vision of security is the well-being and dignity of people, rather than the protection of national borders. $\underline{22}$ Clearly therefore, the human security conception is also 'necessarily attentive to human rights' 23 and does devote as much attention to economic, social, and cultural rights as it does to civil and political rights..24 Indeed, the idea of human rights seems so central to the human security conception that one commentator has even gone as far as arguing that human rights analysis forms the very foundation of human security discourse. 25 It was in fact the palpable dissonance that was caused by attempting to fit the square peg of human rights (and any other such conception of human dignity) into the round hole of the traditional equation of (p.317) security with state security that, in part, necessitated the discursive shift toward the human security end of the security-analysis spectrum.

If, as is suggested by the above analysis, the term 'security' in international law and relations should no longer be seen as a synonym for state security, then the expression collective 'human security' should not as well be equated with collective state security. In accordance with this approach, collective human security ought to be more properly understood in terms of collective human security. To draw from the writings of both Tom Farer and the International Commission on Intervention and State Sovereignty (ICISS), collective human security can therefore be said to refer to the institutionalized commitment to gang up against any state that acts in defiance of collective judgments about what can and cannot be done in regard to the human security of people-that is, their physical, economic, and social well being, and respect for their dignity and worth as human beings. It is in this broader sense that the concept of collective human security will be understood and utilized in the rest of this chapter.

Yet, given the state security-centrism of the dominant collective human security discourse, it is no wonder that until more recently, international human rights institutions (IHIs) such as the African Commission on Human and Peoples' Rights were not generally thought of, and treated with, as significant collective human security resources. Adherence to the human security approach (as the central basis of collective human security thinking and action) is one way of reversing this important historical deficiency in the relevant academic and institutional literature. The human security conception's core embrace of, and focus on, the enjoyment of a broad range of human rights renders most palpable the relevance-indeed centrality-of multilateral institutions such as the African Commission to our contemporary collective human security praxis.

Thus, the main argument that is developed in this chapter is that contrary to the way in which it has been generally imagined in the dominant collective human security literature, the African Commission is by design, and in terms of its institutional practice, an important collective human security resource in Africa. (By a collective human security resource is meant an institution that has contributed or can be pressed to contribute to the multilateral struggle to ensure peace and security (broadly defined) within a particular geographic context.)

In order systematically to develop the main argument that is made in it, this chapter is divided into six major sections; this introduction included. Section 2 provides a short background on the African Commission-the institution that is the focus of our analysis in this chapter. In Section 3, I discuss the normative and textual promise (largely contained within the African Charter) that the African Commission shall, through the effective discharge of its broad human rights mandate, serve as an 
important collective human security resource. Section 4 then systematically considers the institutional practice of the African Commission in this regard, and reaches analytical conclusions as to the quality of its performance. The extent to which the Commission has fulfilled its promise as a collective (p.318) human security resource is an important question that is addressed in this section. In Section 5, I examine the African Commission's prospects as a collective human security resource, and make some recommendations as to what needs to be done to enhance its utility and significance as such a resource. Section 6 summarizes and concludes the chapter.

\section{Brief background on the African Commission on Human and Peoples' Rights $\underline{26}$}

The African Commission on Human and Peoples' Rights (the African Commission) is established by Article 30 of the African Charter on Human and Peoples' Rights (the African Charter). ${ }^{27}$ Although the African system has its intellectual origins in, and owes the impetus for its formation chiefly to, the human rights struggles that took place within African states in the colonial and post-independence eras, $\underline{28}$ it was not until 1986 that the African Charter entered into force and, thus, became legally binding. 29 The African Commission was set up approximately one year later; that is, in 1987.

The African Commission is composed of 11 members (styled 'Commissioners') who are supposed to be chosen from among African personalities of the highest reputation, known for their high morality, integrity, impartiality and competence in matters of human and peoples' rights; particular consideration being given to persons having legal experience. 30

Although in the exercise of much of its mandate, the African Commission tends to function like a quasijudicial body, as with most IHIs, its decisions are formally non-binding.

(p.319) As with the newly created African Court on Human and Peoples' Rights (the African Court),31 with which it enjoys a supplementary, complementary, and cooperative relationship, the African Commission's primary responsibility is to encourage the implementation by African states of the norms contained in the African Charter. Although the full extent of the institutional mandate of the African Commission is articulated in various provisions of the African Charter, as well as in the Protocol on the Rights of Women in Africa (the Women's Protocol), it is in Articles 45 to 62 of the African Charter itself that the mandate is most precisely stated. While Article 45 states, in some detail, the functions of the African Commission, the Commission's mandate-as provided for in that provision-can be summarized under four heads, namely: promotional (including the collection of relevant documents, research, dissemination, and subsidiary law-making); protective (including the consideration of state reports, state communications and petitions from individuals, NGOs, and others); interpretive; and general (involving all other related tasks). To these, Article 46 adds the power to resort to any appropriate means of investigation, while Article 58 authorizes the 'in-depth study' under some circumstances of situations that may involve 'a series of serious or massive violations of human and peoples' rights'.

The substantive human rights norms which are within the promotional and protective remit of the African Commission are stipulated not only in the African Charter, but also in the Women's Protocol and in other 'soft law' instruments that have been formulated and adopted over the years by the African Commission itself. 32 The African Charter contains numerous human rights provisions ranging from economic, social, and cultural rights (such as the right to education in Article 17), through so-called solidarity or third generation rights (such as the right to self-determination in Article 20), to civil and political rights (such as the right to liberty in Article 6). The Women's Protocol adds much detail to the African Charter's specific provision in Article 18(3) for the elimination of discrimination against women and for the protection of their other human rights. For example, because of their relative novelty and greater 
specificity in the context of the textual provisions of African human rights treaties, Article 5 of the Women's Protocol (on the elimination of harmful practices); Article 6 (on consent and equality in marriage); Article 11 (on the protection of (p.320) women in armed conflicts); and Article 14 (on their health and reproductive rights) add value to the attempt to provide adequate human rights protection for women in Africa.

It is fairly clear therefore that the African Commission enjoys a broad human rights promotion and protection mandate. In general, any state party to the African Charter, as well as any individuals, groups of individuals, NGOs, or other such entities may file communications, that is, petitions, at the African Commission alleging a human rights violation by a state party to the Charter.33 In the case of petitions other than by state parties, the locus standi provisions that govern the filing of petitions at the Commission are remarkably generous. 34 Almost any registered NGO or other entity or person (African or foreign) can bring a petition to it without first proving that that entity is in fact the aggrieved party. 35 This is an important instance of the implementation of the concept of actio popularis within an IHI.

On the whole, the African Commission is, of course, part and parcel of the main African human rights system that has been established by the African Charter and its Protocols. And that human rights system is an integral part of the new African Union (AU) that has now replaced the old Organization of African Unity (OAU). Needless to say, this African human rights system was also an integral part of the now defunct OAU. It will be useful to keep this in mind as we analyse the African Commission's collective human security role.

\section{On the collective human security promise of the African Commission}

One does not have to scratch too far beneath the surface of a few relevant and authoritative global documents, such as the Charter of the United Nations (UN Charter), and the UN's An Agenda for Peace and A More Secure World documents, in order to observe and appreciate the intimate connections that the drafters of those documents have very convincingly made between the effective promotion and protection of a broad range of human rights and the eventual attainment of the collective human security ideal. 36 Quite tellingly, Article 55 of the UN Charter mandates that:

With a view to the creation of conditions of stability and well-being which are necessary for peaceful and friendly relations among nations based on respect for the principle of(p.321) equal rights and selfdetermination of peoples, the United Nations shall promote:

1. a. higher standards of living, full employment, and conditions of economic and social progress and development;

2. b. solutions of international economic, social, health, and related problems; and international cultural and educational cooperation; and

3. c. universal respect for, and observance of, human rights and fundamental freedoms for all without distinction as to race, sex, language, or religion.

Similarly, in An Agenda for Peace, then UN Secretary-General Boutros Boutros-Ghali felt able to note that there cannot be ultimate success in the attempt to secure collectively, the security of the globe's peoples until all or almost all of them begin to enjoy a broad range of human rights in far greater measure. 37 In the Preface to A More Secure World, then UN Secretary-General Kofi Annan made essentially the same point when he (impliedly, at the very least) linked what he saw as the need for urgent reform of the now defunct UN Commission on Human Rights to the search for 'a more secure world'. 38 In the main body of the same document, the high-level panel that was constituted by Kofi Annan to 
examine-among other issues-the collective human security challenges that face our world reached a very similar conclusion. 39

It is also fair to say that this 'human rights violation/conflict generation connection' is now recognized in the specific institutional context of the AU.40 In the Preamble to the Constitutive Act of the African Union, separate mention is made of the AU's determination to 'promote and protect human and peoples' rights' and of the fact that 'the scourge of conflicts in Africa' constitutes a major challenge on the continent.41 And although no explicit link is made on the face of that treaty between the protection of human rights and the attainment of collective human security, given the general tenor of other key AU documents, such as the now obsolete Cairo Declaration on the Establishment within the [defunct] OAU of the Mechanism for Conflict Prevention, Management and Resolution 42 and the currently applicable Protocol Relating to the Establishment of the Peace and Security Council of the African Union (the Peace and

Security (p.322) Protocol), 43 it is logical to deduce that the AU leaders who adopted the text of this Constitutive Act were not entirely unappreciative of the linkage between violations of human rights on the African continent and the scourge of conflicts that threaten the peace and security of Africans. But it is para 14 of the Preamble of the Peace and Security Protocol that provides what is perhaps the clearest and most poignant statement in any of the above-mentioned documents of the type of linkage that we are concerned with here. That clause states that the leaders of the AU are aware: of the fact that the development of strong democratic institutions and culture, observance of human rights and the rule of law...are essential for the promotion of collective human security, durable peace and stability, as well as the prevention of conflicts. 44

There is, thus, clear recognition within the AU system of the now well-acknowledged positive linkage between respect for human rights and eventual success in the struggle for peace and security in any given country, region, or continent.

Logically therefore, although such a connection is not adequately articulated in the African Charter-the instrument that created the African Commission-it is only reasonable to argue that since the Commission possesses a broad human rights mandate, and the attainment of peace and security on the African continent is positively linked to the effective promotion and protection of human rights, then the Commission (as a collective inter-African institution) can, at the very least, be said to enjoy a type of derivative collective human security mandate. For, its performance in the present respect (as measured by its fulfilment or non-fulfilment of its human rights mandate) will invariably have a significant impact on the actual enjoyment of human rights in Africa. And when considered in the light of the established connection between the enjoyment of human rights and the attainment of human peace and security, this last fact suggests that the African Commission's performance does-for good or for bad-impact on the peace and security of those humans who inhabit the African continent.

As such, an important question that needs to be asked at this juncture is the extent to which the African Charter does, at the very least, imply this type of linkage (between the Commission's work and human security in Africa), and did design and portray the African Commission as a collective human security resource; thereby promising all who live on the African continent that the Commission will in fact function in that way. Another related question is the extent to which the Commission's status as a collective human security resource appears in the self-image of the African Commission. Has the Commission itself ever promised to act as such a resource? The point here is not, of course, that the answer to these specific questions automatically and completely disposes of the broader question concerning the exact nature of the overall collective human (p.323) security promise of the African 
Commission. However, the answers to these more specific questions will contribute significantly toward the development of an overall response to the broader question.

At the very beginning, it must be noted that, on the whole, there is little doubt that the African

Commission possesses a collective human security role in Africa. As an 11-person, collective, inter-African body that serves as an organ of the AU, the African Commission can reasonably be seen as an institutionalized arrangement within the AU to gang up on any state party to the African Charter that acts in defiance of collective judgments contained in that Charter or made by the African Commission regarding permissible human rights behaviour. 45 This image of the African Commission fits quite well with Tom Farer's well-crafted definition of a collective human security arrangement which was referred to and quoted earlier in this chapter. 46 The image also reflects accurately much of what the Commission does. Among other things, the members of the African Commission metaphorically gang up on nonAfrican Charter compliant (and therefore deviant) states. It does so principally by passing resolutions, making concluding observations on state reports, and indicating its views on petitions brought against states. These pronouncements of the African Commission rely for their authority on the provisions of the African Charter. And these provisions explicate human rights standards that provide general guidance to the Commission as to what can and cannot be done by states parties to the Charter with regard to the security of their people-that is, their physical, economic, and social well-being, alongside respect for their dignity and worth as human beings.

Regarding the first question that was raised above (on the African Charter's design and portrayal of the African Commission as a collective human security resource), it can be said with confidence at the outset that the African Charter did design the Commission to function in that way. Because of space constraints, only some of the available evidence can be discussed here. This evidence will be sourced from the text of the African Charter itself. First of all, Article 23(1) of the Charter guarantees to all peoples the right to national and international peace and security. Article 23(2)(a) enjoins those enjoying the right of asylum in one African country from engaging in 'subversive activities' against their country of origin. Article 23(2)(b) further enjoins all African states not to allow their territories to be used as bases for subversive or terrorist activities against the people of any other state party to the Charter. Logically, to charge the African Commission with monitoring the implementation of these provisions by states parties was to, in effect, promise that the Commission will, via the discharge of these functions, serve as a collective human security resource. For, when a multilateral institution, such as the African Commission gangs up on a state in order to help guarantee human security, it is clearly the case that that body is at the very least acting as (p.324) a collective human security resource. Such a body will also be acting as such a resource if it functions in a way that helps guarantee to some extent that subversive or terrorist activities are not launched against any state from within the boundaries of another state. Secondly, very similar arguments can be made in respect of the provision in Article 19 of the African Charter that 'nothing shall justify the domination of a people by another'. State fragmentation and the domination of minority groups have clearly been one major source of conflicts in Africa. $4 z$ No wonder then that the African Charter also provides in Article 20 that 'all peoples shall have a right to existence [an articulation of the prohibition of genocide]' and that 'colonized or oppressed peoples shall have the right to free themselves from the bonds of domination by resorting to any means recognized by the international community'. Both of these guarantees are designed to ensure much deeper respect for sociocultural difference and other minority rights against a general historical background of the existence on the African continent of far too many low-level or intense intra-state conflicts that have resulted from minority repression. $4^{8}$ Such conflicts are a key source of insecurity in Africa. 49 That the African 
Commission is charged with the quasi-adjudication of disputes relating to the guarantees in Articles 19 and 20, disputes that often relate to the prevention or just resolution of violent conflicts, provides further evidence of the type of collective human security role that the Commission was designed to play.

Thirdly, although the provision in Article 22 of the African Charter that 'all peoples shall have the right to their economic, social and cultural development' and that 'states shall have the duty, individually and collectively, to ensure the exercise of the right to development' fits far better with the human security approach than it accords with the traditional state security paradigm, by mandating the African Commission to monitor the implementation of these provisions by African states, the African Charter in effect conferred a collective human security function on that Commission. As has been demonstrated by adherents of the human security approach, there is a positive connection between the economic, social, and cultural development of a people and their security situation.50 As such, any effort on the part of the African Commission to encourage the greater economic, social, and cultural development of any African people is at the very same time an effort to advance the security interests of those same people. It is in this sense therefore that the inclusion of these provisions as part of the African Commission's remit provides additional evidence of its collective human security promise.

Lastly, and perhaps less importantly, para 9 of the Preamble of the African Charter does state that the states parties that adopted that Treaty in 1981 did so (p.325) in part because they were aware of the need to, among other things, 'dismantle aggressive foreign military bases'. The presence of such foreign bases and interventionist forces has for long been a significant source of insecurity on the African continent. As such, the adoption by African states of an African Charter which, albeit in a preamble, sought the dismantling of those foreign bases at the same time as they created an African Commission to monitor the implementation of that Charter's mandate was therefore one way of affirming the Commission's collective human security role. At the very least, this shows that collective human security was one of the issues on the minds of the creators of the African Commission.

While it is possible to offer numerous other examples of the ways in which the African Charter designed and portrayed the African Commission as a collective human security resource by charging that multilateral institution to gang up and express negative views or take other suitable action against any state that deviates from explicitly stated Charter norms about permissible behaviour, the above examples suffice to ground and illustrate this first argument.

Regarding the second question that was raised at the beginning of this section (on the presence of a collective human security role within the African Commission's self-image), it suffices in order to make the intended point to refer to, and discuss, the Commission's response to one of the most important collective human security challenges in contemporary African history, the Rwandan genocide, as well as to the African Commission's 1994 Resolution on the Situation of Human Rights in Africa. 51 As the Commission's Resolution on the Rwandan genocide will also be discussed in the next section of this chapter, its consideration here will be necessarily brief and focused on the specific point that is sought to be made. The tone and tenor of the African Commission's Resolution on Rwanda52 clearly shows that the African Commission does, at the very least, imagine certain collective human security problems as within its remit. It also suggests that it imagines itself, at least in part, as a collective human security resource. Merely passing a Resolution on the Rwandan crisis-a quintessential collective human security problemindicates that the African Commission surely thinks of itself as seized of some significant role in bringing about a long-term solution to that problem. 
Similarly, in its Resolution on the Situation of Human Rights in Africa, the Commission expressed its deep concern with what it referred to as 'the consequences of persistent wars in several African states, on the civilian population' and called on 'all those parties engaged in war on the African continent, to abide (p.326) by the provisions of International Humanitarian Law...and to undertake all efforts to restore peace'. Here again, the Commission's words and actions suggest that it imagines itself as seized of some type of collective human security function. Since the Commission is unarguably a multilateral institution, and given that that body clearly regards the issue of war and peace, and the conduct of war, as within its purview and remit, then - as a body that is supposed to express the collective will of African peoples in the human rights area-the Commission definitely possesses a collective human security role. More importantly for the specific argument being made in this section of the chapter, as has been shown here, the Commission itself has recognized that it can play and does play such a role in Africa. 53 Having systematically made the points clear that the African Commission was from its very beginnings conferred a collective human security role, that this multilateral institution was designed and portrayed in its constitutive instrument as a collective human security resource, and that the African Commission has itself recognized this collective human security role as within its mandate, it remains to examine in some detail the extent to which the Commission has in its institutional practice performed this collective human security function and lived up to its billing in the African Charter as a collective human security resource. Following that discussion, the prospects for the enhanced utilization of the Commission as such a resource will be considered. A concluding section will follow this latter discussion.

\section{Collective human security: the performance of the African Commission}

To what extent has the African Commission's actual practice lent itself to the conclusion that the Commission has in fact functioned as a collective human security resource? And if the Commission has in fact functioned in this way, to what extent has its performance been adequate? In other words, what exactly has the African Commission done about what Mgbeoji has famously referred to as 'collective [human] insecurity' on the African continent?54

The reasonably detailed examination of the African Commission's practice that follows will be conducted under the following heads: the right to national and international peace and security; regional selfdetermination and minority rights; and the right to their economic, social, and cultural development (in relation to the enjoyment of economic, social, and cultural rights). This corresponds to the categories around which most of the discussion in the previous section was (p.327) organized. Due to limitations of space, not every possible such topic has been included and considered.

\subsection{The right to national and international peace and security}

Regarding the African Commission's institutional practice with respect to the guarantee in the African Charter of the right to national and international peace and security, the discussion below of a number of the Commission's Resolutions serves to illustrate how that body has in practice played a collective human security role by, among other things, formulating and providing important normative resources to those who struggle for the attainment of peace and security in Africa. For example, para 5 of the African Commission's Resolution on Rwanda55 provides a good indication as to how a significant portion of the African Commission's practice demonstrates that it has in fact functioned to an appreciable extent as a collective human security resource. In that Resolution, the Commission, among other things, urged Rwanda: 
to prevent the perpetration of acts of reprisals and vengeance by the rapid establishment of a new police force and a local administration respectful of human rights and composed of members of all ethnic groups of Rwanda. 56

In para 6 of the same Resolution, the Commission also urges Rwanda to ensure the 'strengthening of the interceding peace-keeping forces throughout Rwanda'. A fuller consideration of the text of that Resolution suggests that the African Commission passed this Resolution in order to urge the view upon Rwanda and other actors that adherence to human rights norms in the governance and reconstruction of post-genocide Rwanda was the path dictated by the African Charter and was also the better way to ensure that peace and security was maintained and sustained in that country. The African Commission was in practice trying to provide normative support for the collective African attempt to promote human security in that recently troubled country. As a multilateral institution that is designed to pressure and persuade states, rather than to coerce their compliance, the African Commission's aim here was to pile normative pressure on Rwanda to act in the way the Commission considered appropriate. It matters little in this case whether the Commission's efforts were successful in the end. For the body's role is to serve as a resource and not a collective human security panacea. It clearly served the former function.

Another example of the African Commission's institutional practice with respect to the implementation of the African Charter's guarantee of the right to peace and security is the Commission's adoption of its Resolution on Anti-Personnel Landmines.5z The adoption of this document also provides evidence of (p.328) the African Commission's real-life institutional practice of its collective human security resource role. Needless to say, landmines are a serious source of human insecurity in much of Africa and their deployment or use is increasingly seen as contravening the rules of permissible conduct even in war time. This particular Resolution of the African Commission can therefore be seen as a 'ganging up' at the collective African level against states (or even other actors) that have contravened this rule. In this sense the Commission's anti-landmine practice, as represented in this Resolution, can be read as evidence that it has actually functioned (at least in part) as a collective human security resource.

Another example of the African Commission's practice in relation to its broad monitoring of the efforts made by states to ensure the practical implementation of the right to peace and security that is guaranteed in the African Charter is the fact that the Commission has adopted a number of Resolutions through which it has sought to intervene in some way in order to help end, and/or shape the peace agreements that ended a significant number of conflicts on the African continent. In its Resolution on the Sudan, 58 it called on

all parties to the [then raging SPLA/SSIA v Sudanese Government] armed conflict immediately [sic] to cease using military force to interfere with the delivery of humanitarian assistance to the civilian population 59

and appealed to

the Government of the Sudan to support negotiations for a settlement to the conflict and ensure that any agreement includes strong guarantees for the protection of human rights. $\underline{60}$

In the more recently adopted of the African Commission's two major Resolutions on the Darfur conflict, namely the Resolution on the Situation in Darfur, 61 the Commission began by recalling the earlier Resolution that it had adopted on the same situation, and ended up calling on: the parties to the conflict in the Darfur to observe the terms of the Ceasefire Agreements concluded in Ndjamena, Tchad, and to resume negotiations in Abuja, Nigeria, under the auspices of the current 
Chairman of the African Union, President Olusegun Obasanjo of the Federal Republic of Nigeria, with a view to finalize a permanent ceasefire and a Comprehensive Peace Agreement on the conflict in the Darfur. $\underline{62}$

In its Resolution on Liberia, 63 the African Commission noted that up to that point, the warring factions had refused to disarm, 64 endorsed 'the Abuja Peace (p.329) Accord as the best means for the cessation of hostilities and restoration of peace to Liberia', $\underline{65}$ and among other things, called on all 'the Warring Factions to take all necessary steps to disarm their fighters'. 66 In the Commission's Resolution on South Africa, 67 it condemned 'very strongly the cycle of violence and the massacre of innocent civilians by the different armed factions [to the conflict that attended the transition from apartheid to democracy in that country]'. And in its Resolution on Burundi, $\underline{68}$ the Commission, decided to 'involve itself more in efforts to resolve the crisis affecting Burundi by, among other things, sending a mission to Burundi and participating actively in the process of national reconciliation'. 69

All the examples discussed above serve to demonstrate that the African Commission has to a significant extent done what the African Charter mandated, and in fact did promise that it would do. More specifically, these examples show that the Commission has in practice actually made efforts to encourage the implementation of the right to peace and security that is guaranteed in the African Charter; and that it did so in ways that clearly suggest that it has served as a significant collective human security resource.

\subsection{Regional self-determination and minority rights}

The significance of the African Commission's efforts to encourage states parties to the African Charter to implement those provisions of the Treaty that guarantee regional self-determination and other minority rights can be illustrated by the following examples. First of all, in Katangese Peoples' Congress $v$ Zaire (the so-called Katanga case), zo the Commission played an important normative and signalling role in the admittedly still incipient attempt at the inter-African level to construct a more conducive sociopolitical and legal environment for the amelioration of many of the grievances of sub-state groups on the African continent. ${ }^{21}$ In that case, a communication, alleging the denial of Katanga's right to selfdetermination, including its right to independence from the country then known as Zaire (now the Democratic Republic of the Congo), was submitted on behalf of the Katangese Peoples' Congress. It requested the African Commission to, among other things, recognize the independence of Katanga; and recognize that body as a liberation movement entitled (under Article 20 of the African Charter) to support in the achievement of independence from (p.33o) Zaire.72 Among other things, the African Commission held that:

In the absence of concrete evidence of violations of human rights to the point that the territorial integrity of Zaire should be called into question and in the absence of evidence that the people of Katanga are denied the right to participate in Government...the Commission holds the view that Katanga is obliged to exercise a variant of self-determination that is compatible with the sovereignty and territorial integrity of Zaire.73

The clear implication of this very important decision is that an oppressed sub-state group has a conditional (if exceptional) right to secede from its parent state if it could show that the treatment meted out to members of the group by the relevant state is so intolerable when adjudged against the human rights barometer as to justify such a radical measure. 74 Thus, no longer can an African state deal ruthlessly and highly oppressively with a sub-state group and yet demand that inter-African institutions such as the Commission ratify and support its forcible retention of such a group within its borders. Thus, 
the signal that was sent by this decision was that if a state wants normative or legitimizing support from the African Commission in an effort to maintain its integral existence, then it must find relatively nonoppressive ways of retaining its sub-state groups.

Lending further support to its decision in the Katanga case to interpret the African Charter's guarantees of certain rights to entities referred to as 'peoples' as beneficial to sub-state groups, in the subsequent Ogoni case,75 the Commission accepted-by implication-that sub-state groups, including those that form minorities, qualify to be referred to as 'peoples' within the meaning of the relevant provisions of the African Charter. The complaints made on behalf of 'the Ogoni population' by the Nigeria-based Social and Economic Rights Action Center (SERAC) and the US-based Center for Economic and Social Rights was accepted and declared successful without any argument as to whether 'the Ogoni population' constituted a 'people' under the African Charter. In this way the African Commission has also helped develop the law of minority rights in Africa, thereby contributing to the strengthening of the normative resources available to such groups as they struggle for greater equity and justice within the states that en-globe them. The collective human security role played here by the Commission is evident from the fact that the intra-state conflicts that too often result from the lack of adequate equity and justice in 'state v minority group' relations are a serious problem in Africa, as the world over.

The African Commission's Resolution on Rwanda also illustrates its efforts to further the implementation in that country of the African Charter's guarantee in its Article 19 of the right of all peoples (that is, intrastate or so-called (p.331) ethnic groups) to equality with, and freedom from domination by, more powerful groups. It illustrates the Commission's attempt to further the implementation of the implied right of minority and other such groups to be fully included in all aspects of the governance of their countries. In that Resolution, the Commission urged the post-genocide government of Rwanda to ensure the 'rapid establishment of a new police force and a local administration...composed of members of all ethnic groups of Rwanda'.76

Another example of the ways in which the African Commission has in practice sought to further the implementation of, and breathe some life into, the regional self-determination and minority rights provisions in Article 20 of the African Charter (and so on) is through the activities of its Working Group on Indigenous Populations and Communities. For instance, this working group has undertaken factfinding missions to certain African countries (such as Burundi in March/April 2005); and launched its report in Geneva at a session of the now defunct UN Commission on Human Rights (in April 2005).77 In addition, this working group, from time to time, organizes seminars on the indigenous rights question in Africa. For instance, one such seminar was organized in Yaounde, Cameroon in September 2006.78 This was the first in a series of regional seminars earmarked by the working group so as to foster dialogue with relevant stakeholders on the rights of indigenous peoples in Africa, and thereby help promote and protect the rights of such populations on the continent.79

These examples suffice to illustrate the ways in which the African Commission's actual institutional practice in the regional self-determination and minority rights area bears out the characterization of the Commission in this chapter as a significant collective human security resource. By striving to promote and protect this category of rights, the Commission has at the same time helped further the search for peace and security in Africa. As a multilateral African institution that functions as an organ of the AU, the Commission's work has expressed the collective human security ambitions of the AU.

\subsection{The enjoyment of economic, social, and cultural rights}


As has been noted earlier in this chapter, the broader human security approach and optic appreciates and integrates within it the now well-acknowledged truism that the enjoyment by a given population of the types of economic, social, and cultural rights (ESC rights) guaranteed in various provisions of the African Charter is essential to their security. As such, efforts by the African Commission (p.332) to promote and protect these ESC rights are in themselves attempts on the part of that institution to facilitate the enjoyment by the relevant populations of their human security. This is why it is important at this point to consider the Commission's performance with regard to the promotion and protection of ESC rights.

A caveat must, however, be entered at the outset. This is that the African Commission's engagement with ESC rights has occurred within, and has been shaped by, a broader social context in which ESC rights have tended not to be treated seriously in the dominant human rights approaches. $\underline{80}$ As importantly, 'only a modest number of socio-economic rights are explicitly included in the [African] Charter' and 'some prominent socio-economic rights [such as the rights to food, water, social security, and housing] are not mentioned by name' in that Charter. $\underline{81}$ What is more, the fact that only a few ESC rights cases (such as the Ogoni ${ }^{82}$ and Purohit ${ }^{83}$ communications) have been brought before the Commission by the relevant actors demonstrates the fact that the African Commission (and the non-state actors that have supplied it with almost all of its petitions) have, on the whole, not been as attentive to the protection of ESC rights on the continent as they could have been. $\underline{8} 4$ Compared to the Commission's engagement with civil and political rights communications, the number of ESC rights communications that it has considered so far has been 'minimal'. $\underline{85}$

Nevertheless, the African Commission has, of course, engaged to some extent with the ESC rights provisions contained in the African Charter. Its efforts have resulted in the development of norms in this area. In the now famous Ogoni case, the Commission expressed views that have been described by Christof Heyns as 'extraordinary'. .66 In that case, the complainants alleged (on behalf of the Ogoni population of Nigeria) that the then military government of Nigeria had systematically violated the rights to health, environment, housing, and food of the Ogoni, and had also violated the right of the Ogoni to be free from the capture, spoliation, and dispossession of their natural resources. $\frac{8 z}{}$ In finding in favour of(p.333) the complainants on virtually all scores, the African Commission, among other things, read the rights to housing and food into the African Charter. $\underline{88}$ Those rights are not explicitly articulated in that Charter. $\underline{89}$ If it is understood that the enjoyment of the ESC rights of any people to health, environment, housing, food, and to be free from the dispossession of their natural resources are key to their enjoyment of human security, then the contribution of the African Commission's jurisprudence in this case to the search for collective human security in Africa becomes palpable. In the Purohit case, two mental health advocates brought a complaint against the Gambia on behalf of patients detained at 'Campana', a psychiatric unit of the Royal Victoria Hospital in that country. The complainants alleged violations by the Gambia of certain provisions of the African Charter. Their complaint centred on the character of that country's Lunatics Detention Act (LDA), the principal statute that governed mental health care there. On the whole, the LDA imposed a scheme that authorized the automatic and indefinite detention of persons labelled 'lunatics'. 90 In holding for the complainants, the African Commission wrote a decision that has helped tremendously in the development and activation of the mental health dimensions of the 'right to health' provisions of the African Charter. Among other things, the Commission expressed its awareness that a significant portion of the deprivations of the right to health that occur in Africa stem from the poverty of many African countries and, as such, it read into Article 16 of the African Charter, the obligation on the part of the states parties to the African Charter to 
take concrete and targeted steps while taking full advantage of its available resources, to ensure that the right to health is fully realized in all its aspects without discrimination of any kind. 91

It also found that the scheme of the LDA is 'lacking in terms of therapeutic objectives as well as [the] provision of matching resources and programs of treatment of persons with mental disabilities', and as such, violated Articles 16 and 18(4) of the African Charter.22 The African Commission's development of the ESC rights provisions discussed above cannot but have enhanced the normative resources available for those who struggle to improve the ESC rights situation in Africa. And since the enjoyment of ESC rights is essential to the success of the search for peace and security, the Commission has-in this significant way-contributed to the collective struggle for security on the African continent.

What is more, the African Commission has, through other means, also sought to promote and protect the enjoyment of ESC rights in Africa. For instance, it has organized at least one major seminar on this question. 93 A significant (p.334) dividend yielded by this seminar was the adoption by the African Commission of a Resolution on Economic and Social Rights. 94 In that Resolution, the Commission established a Working Group on ESC Rights; urged its 'Special Rapporteurs and Working Groups to pay particular attention to economic, social and cultural rights during their missions and in the discharge of their respective mandates';9.5 and adopted a very detailed and well articulated statement on ESC Rights, namely: the Pretoria Statement on Social, Economic and Cultural Rights in Africa. ${ }^{66}$ What is more, the preamble of this Resolution reflects the depth of the African Commission's recognition and appreciation of the relationship between the deplorable ESC rights situation in Africa and the seriousness of the peace and security challenges that face all too many African countries. In its own words, it expressed its concern about 'the lack of human security in Africa due to prevailing conditions of poverty and underdevelopment and the failure of African states to address poverty through development'. 27

Clearly, therefore, given the importance of the promotion and protection of ESC rights to the struggle for peace and security in Africa, the African Commission has (to the same extent that it has made the kinds of efforts discussed above) contributed in some measure to the struggle for collective human security on the African continent. This is, therefore, one of the important ways in which the Commission has, in practice, functioned as a collective human security resource.

\section{The African Commission's prospects as a collective human security resource}

In order to reach an accurate understanding of the prospects for the continued functioning of the African Commission as a significant collective human security resource, it is important first to assess and understand the extent to which institutional practice in this regard has, over time, met reasonable expectations as to its performance. The assessment of the Commission's collective human security prospects that will be undertaken here will be organized around the same three sample areas of the Commission's work in the relevant regard(p.335) which have already been examined in each of the two previous sections of this chapter.

However, to be useful, such an assessment must be based on a realistic barometer; that is to say, that the standard of measure must be appropriate to the task at hand. It is thus important not to overestimate the capacity of even the most ideally functioning international institution to contribute to peace and security within specific polities. 98 It is important to keep in mind the fact that international institutions are not designed to act as panaceas for problems of insecurity (or any other problem for that matter). They are rather much more humbly constructed as resources to be mobilized by other actors (such as states, nongovernmental organizations, sub-state groups, and individuals). Even the best designed and functioning international institution cannot on its own (or even in alliance with other such institutions) assure collective human security to any given people. Other forces will condition, shape, and limit such an 
institution's role. A keen awareness of the inevitable limitations on the capacity of international institutions such as the African Commission to contribute to collective human security (or to any other value for that matter) will allow for a much more realistic assessment of both its attainments to date and its prospects in the future. In consequence, the African Commission's actual performance as a collective human security resource will be assessed against what it could possibly have achieved, and not against what it might have achieved in an ideal world. The world in which the Commission and other such bodies operate is, of course, far from ideal.

In relation to the African Commission's work on the implementation of the general guarantee in the African Charter of the right to national and international peace and security, the Commission deserves reasonably high marks, on the whole, for discharging relatively well its possible collective human security role. Given the Commission's design as an IHI that is possessed of only hortatory powers, it could not reasonably have been expected to do much more than it has already done in this area. As discussed in Section 4, it has passed several important Resolutions on various relevant subjects and situations (for example, landmines, Rwanda, the Sudan, Liberia, South Africa, and Burundi). These Resolutions contained the appropriate normative language, and were virtually always directed to the appropriate quarters. While it is always possible for a body such as the African Commission to do more in this highly important regard, given its (inherent) character as a body that persuades and cannot compel, there wasin practice-little else that the Commission could have done.

By contrast, however, commendable as it is, the African Commission's efforts to implement the selfdetermination and minority rights provisions in the African Charter (and in so doing, further its role as a collective human security resource), (p.336) do not deserve as high a grade. Certainly, the Commission's reasoning in the Katanga case was, to say the least, bold and commendable. This decision has undoubtedly made an important contribution to our understanding of the right to sub-state group selfdetermination and minority rights, not only in Africa, but also the world over. The Commission's other efforts in this area (for example, its Working Group on Indigenous Peoples/Communities, the Ogoni case, and its Resolution on Rwanda) are also commendable. Nevertheless, given the centrality of the denial to sub-state groups of their self-determination and minority rights to the insecurity that plagues far too many portions of the African continent, 99 the African Commission's efforts in this specific area of its collective human security mandate have not been as adequate as they could have been. For one thing, despite its efforts toward the drafting and adoption of instruments such as the recently concluded Women's Protocol (which details and deepens women's rights provisions in the African Charter) 100 and the Fair Trial Guidelines (that expand on the fair hearing provisions in the African Charter), 101 very little, if anything, has been done by the Commission toward the drafting and adoption of a detailed Protocol or Resolution that explicates in much greater detail the minority protection rights that sub-state groups in Africa are to enjoy. Given the normative/hortatory utility of such a detailed document to the work of the activists who struggle on behalf of sub-state groups in Africa, and the centrality of the ill-treatment of substate groups to the insecurity that exists in much of the African continent, this gap in the law-creating activities of the African Commission is, it is submitted, a major one. Secondly, although the Commission has most commendably appointed a working group on the rights of indigenous peoples in Africa, it needs to work toward the establishment (within or without it) of a specialized mechanism for the third party (that is supra-state) 'adjudication' of the rights claims made by sub-state groups against the states of which they form a part. Such a mechanism should be able to focus on preventing internecine conflict, even before a related case is brought before the African Commission. The Commission also needs to 
undertake more explicitly focused promotional work in the sub-state group self-determination and minority rights area. More therefore needs to be done by the African Commission with regard to strengthening its work in this general area if it is to discharge its Charter-mandated collective human security obligations more effectively.

Such strengthening will also be required with regard to the African Commission's work in the ESC rights area. As has been discussed above, it is (p.337) well recognized in the relevant literature that the African Commission has been relatively inattentive to the protection of ESC rights on the continent.102 As such, the burden that rests on the shoulders of the African Commission to interpret the ESC rights provisions of the African Charter appropriately and develop its own ESC rights jurisprudence is quite considerable. As the Ogoni case indicates, 'the approach of the Commission in filling the [ESC rights] gaps in the Charter' has been 'creative and bold'. ${ }^{103}$ Yet, while its activities in the area of ESC rights have been increasingly significant in both quantitative and qualitative terms, much more still needs to be done by the African Commission in this area if it is more effectively to discharge its collective human security role in Africa. The link between the enjoyment of ESC rights and the attainment of human security is now so clear that no further explication is required here. By contributing much more to the enjoyment of ESC rights, the African Commission will greatly enhance its role as a useful collective human security resource on the continent.

Nevertheless, it is acknowledged that the African Commission's collective human security efforts have been hampered by all the institutional and other problems (mostly beyond its control) that it has faced since inception. These problems are well documented in the relevant literature.104 Some of the more serious and relevant of these problems include: the Commission's lack of adequate financial (p.338) and human resources; 105 the insufficient publicity that the Charter and the African Commission's work have received so far; $; 06$ and a weak 'state-compliance' record.107

Although these problems have each contributed in some measure (but not necessarily evenly) to the inability of the Commission to fully realize its potential as an important collective human security resource, as I have argued elsewhere, the greatest promise for the more adequate realization of the humanist promise of the African Commission (and the other institutions of the African human rights system) lies not as much in the character of the Commission itself or what it does itself, but more in the ability of domestic activist forces creatively to deploy the Commission's views, decisions, resolutions, and other such resources within their own domestic institutions (such as their national courts and legislatures). .108

Overall, however, Joe Oloka-Onyango has (for understandable reasons) felt able to declare that 'unfortunately, even the most positive reviews of the performance of...the African Commission...generally agree that the institution has performed at less than par'. ${ }^{109}$ Yet, as Nsongurua Udombana has more recently concluded, 'the African Commission has come a long way since its inauguration in 1987. In its early years, the Commission was more careful than courageous...it now interprets its mandate boldly and creatively.' 110 A similar conclusion has been reached by Christof Heyns, another very knowledgeable observer of the African Commission. 111

In view of this increasing, albeit incremental, innovativeness and boldness on the part of the African Commission, it is not unreasonable to conclude that the Commission will, as time goes on, grow in capacity, creativity, boldness (and therefore stature). As such, it is also fair to suppose that that interAfrican human rights mechanism is more likely than not to become better able to discharge its functions more satisfactorily. If this turns out to be true, then the Commission is also as likely to function much 
better as a collective human security resource. Without such increased creativity and boldness, it will be extremely difficult for an African Commission that is in practice equipped with only hortatory power to make an appreciable impact within the high-stakes world of realpolitik in which a considerable portion of collective human security issues are still dealt with. Even the non-military/state security and more human rights issues that affect human security in Africa (such as questions of food security) are all too often seen as part of a high-stakes global political game of sorts. Thus, it is in part because the African Commission's developing institutional posture tends to suggest that it will get even bolder and more innovative as time goes by that a relatively optimistic reading of its prospects as a collective human security resource is offered here. (p.339)

\section{Conclusion}

The chapter began with some background and definition of the key concepts and terms which are analysed and discussed. Subsequently, the intimate and positive link between the enjoyment of a broad array of human rights and the success of the collective human security effort in our time was noted and discussed. Thereafter, a brief background discussion of the nature and character of the African Commission (the pan-African institution that was focused on in this chapter) was offered. It was shown that this linkage is now well recognized by both the United Nations and the AU. Thereafter, a detailed discussion of the extent to which the African Charter-the 'Constitution' that governs the activities of the African Commission-designed and portrayed that Commission as a collective human security resource was undertaken. It was also shown that the African Commission itself accommodates this collective human security resource role in its construction of its self-image.

The above discussions presaged a detailed examination of some of the ways in which significant aspects of the African Commission's institutional practice justify that body's characterization in this chapter as a significant collective human security resource. The chapter concludes with some thoughts on the African Commission's prospects as a collective human security resource.

Notes:

(1) eg, see JS Sutterlin, The United Nations and the Maintenance of International Security (Westport, CT: Praeger, 2003), 81; A More Secure World: Our Shared Responsibility, Report of the Secretary General's High-Level Panel on Threats, Challenges and Change (New York: United Nations, 2004) (hereinafter 'A More Secure World'), viii, ix, 5, 23-56, and 88-90; and JF Jones, 'Human Security and Social Development' (2004) 33 Denver Journal of International Law and Policy 92, 95-102.

(2) J Moore, 'Collective Human Security with a Human Face: An International Legal Framework for Coordinated Action to Alleviate Violence and Poverty' (2004) 33 Denver Journal of International Law and Policy 43, 44-5.

(3) I Mgbeoji, Collective Insecurity (Vancouver: University of British Columbia Press, 2003), 49.

(4) Ibid, 53. See also S Fukuda-Parr et al, 'Preface' in L Chen et al (eds), Human Insecurity in a Global World (Cambridge, MA: Asia Center of Harvard University, 2003), vii; L Gordenker and TG Weiss, 'The Collective Human Security Idea and Changing World Politics' in TG Weiss (ed), Collective Human Security in a Changing World (Boulder, CO: Lynne Rienner, 1993), 3, 7; and SN MacFarlane and YF Khong, Human Security: A Critical History (Bloomington, IN: Indiana University Press, 2006), 1.

(5) A-M Slaughter, 'A New UN for a New Century' (2006) 74 Fordham Law Review 2961, 2963. 
(6) L Gordenker and TG Weiss (see n 4 above) 3 .

(z) T Farer, 'The Role of Regional Collective Human Security Arrangements' in Ibid, 155.

(ㅁ) SN MacFarlane and YF Khong (see n 4 above) 1.

(9) L Pettiford and M Curley, Changing Security Agendas and the Third World (London: Pinter, 1999), 108.

(10) 'A More Secure World' (see n 1 above) [Synopsis] 11. See also A-M Slaughter, 'Security, Solidarity, and Sovereignty: The Grand Themes of UN Reform' (2005) 99 American Journal of International Law $619,620$.

(11) eg see Mgbeoji (n 3 above) 53; VP Nanda, 'Preemptive and Preventive Use of Force, Collective Human Security, and Human Security' (2004) 33 Denver Journal of International Law and Policy 7, 10; and A-M Slaughter (n $\underline{10}$ above) 619.

(12) SN MacFarlane and YF Khong (see n 4 above) 1. See also JF Jones ( $\mathrm{n}$ above) 94-5.

(13) See n 5 above, 2963.

(14) VP Nanda, ibid, 11; and S Fukuda-Parr et al (see $\mathrm{n} 4$ above) vii.

(15) See $n 9$ above, 115.

(16) S Fukuda-Parr, 'New Threats to Human Security in the Era of Globalization' in L Chen (see $\mathrm{n} 4$ above) 1.

(17) See n 5 above, 2963-4.

(18) S Fukuda-Parr, 'New Threats' (see n $\underline{16}$ above) 15.

(19) Report of the International Commission on Intervention and State Sovereignty, 'The Responsibility to Protect', 15, 〈http://www.iciss.ca/pdf/Commission-Report.pdf $\rangle$. For some other important definitions, see Report of the Commission on Human Security, 'Human Security Now' (2003) 4, http://www.humansecurity-chs.org/finalreport/English/FinalReport.pdf $\rangle$ and UNDP, Human

Development Report 1994 (New York: Oxford University Press, 1994), 23.

(20) SN MacFarlane and YF Khong (see n 4 above) 2 (emphasis added).

(21) D Newman, 'A Human Security Council? Applying a "Human Security" Agenda to Security Council Reform’ (2000) 31 Ottawa Law Review 213, 215.

(22) Ibid.

(23) Ibid, 219.

(24) Ibid, 222. 
(25) JF Jones (see n $\underline{1}$ above) 95-102.

(26) Very small segments of this section are reproduced from ch 3 of OC Okafor, The African Human Rights System, Activist Forces and International Institutions (Cambridge: Cambridge University Press, 2007).

(27) African Charter on Human and Peoples' Rights, 1981 (in force 1986), reproduced in C Heyns (ed), Compendium of Key Human Rights Documents of the African Union (Pretoria: Pretoria University Press, 2005), 20. For more on the nature and functioning of the African Commission, see $\mathrm{R}$ Murray, Human Rights in Africa: From the OAU to the AU (Cambridge: Cambridge University Press, 2004); R Murray, The African Commission on Human and Peoples' Rights and International Law (Oxford: Hart Publishing, 2000), 29; M Mutua, 'The African Human Rights System in a Comparative Perspective' (1993) 3 Review of the African Commission on Human and Peoples' Rights 5, 11; CE Welch Jr, 'The African Commission on Human and Peoples Rights: A Five Year Report and Assessment' (1992) 14 Human Rights Quarterly 43; EA Ankumah, The African Commission on Human and Peoples' Rights (The Hague: Martinus Nijhoff, 1996); CA Odinkalu, 'The Individual Complaints Procedure of the African Commission on Human and Peoples' Rights: A Preliminary Assessment' (1998) 8 Transnational Law and Contemporary Problems 359; and OC Okafor, 'The African System on Human and Peoples' Rights, Quasi-Constructivism, and the Possibility of Peacebuilding within African States' (2004) 8 International Journal of Human Rights 413 (hereinafter 'Peacebuilding').

(28) M Mutua, 'The Banjul Charter and the African Cultural Fingerprint: An Evaluation of the Language of Duties' (1995) 35 Virginia Journal of International Law 339, 346-64.

(29) Ibid, 339-40.

(30) African Charter on Human and Peoples' Rights (see n $\underline{27}$ above) Art 31.

(31) The African Court was established by the Protocol to the African Charter on Human and Peoples' Rights on the Establishment of an African Court on Human and Peoples' Rights, 1998, in force 2004, reproduced in C Heyns (ed), Compendium of Key Human Rights Documents of the African

Union (Pretoria: Pretoria University Press, 2005), 32. As its judges have now been elected and its location chosen, the Court should be fully functional very soon.

(32) eg, see the African Commission on Peoples' Rights, Resolution on the Right of Recourse and Fair Trial, 11th Ordinary Session (2-9 March 1992), reproduced in the African Commission on Peoples' Rights, Recommendations and Resolutions (the African Commission on Peoples' Rights, Banjul, The Gambia, 1998), 16; Resolution on the Right to Freedom of Association, 11th Ordinary Session (2-9 March 1992) reproduced ibid, 18; Resolution on the Promotion and Respect of International Humanitarian Law and Human and Peoples' Rights, 14th Ordinary Session (1-10 December 1993) reproduced ibid, 21; and Resolution on the Military (25 October-3 November 1994) reproduced Ibid, 26.

(33) CA Odinkalu (see n 27 above) 369-74.

(34) Ibid, 378-9.

(35) African Charter on Human and Peoples' Rights (see n 27 above) Art 55. 
(36) See Charter of the United Nations (26 June 1945) 3 Bevans 1153; Report of the UN Secretary General, 'An Agenda for Peace: Preventive Diplomacy, Peacemaking and Peacekeeping' (17 June 1992) A/47/277, 5 and S/24111, 15, 〈http://www.un.org/docs/SG/agpeace.html $\rangle$ and 'A More Secure World' (n 1 above) ix, 5, and 88-90.

(37) ‘An Agenda for Peace’, ibid.

(38) ‘A More Secure World', ibid, ix.

(39) Ibid, 88-90.

(40) R Murray, Human Rights in Africa (see n $\underline{27}$ above) 117.

(41) Constitutive Act of the African Union, 2000, in force 2001, reproduced in C Heyns (ed) (see n 31 above) 4 .

(42) This mechanism was established in 1993 by the Cairo Declaration (28-30 June 1993) OAU Doc AHG/Decl.3 (XXIX), 〈http://www.africaunion.org/root/AU/Documents/Decisions/hog/3HoGAssembly1993.pdf\#search=\%22Cairo\%20Declarati on\%20on\%2othe\%20Establishment\%20within\%2othe\%20OAU\%20of\%2othe\%2oMechanism\%2ofor\%2 oConflict\%20Prevention\%2C\%20Management\%20and\%20Resolution\%22〉 . It was initially incorporated into the new AU order by the 'Decision on the Implementation of the Sirte Summit Decision on the African Union' (11 July 2001) OAU Doc AHG/Decl.3 (XXXVII),

http://www.au2002.gov.za/docs/key oau/sirte au.pdf\#search=\%22Decision\%20on\%20the\%20Implem entation\%200f\%20the\%20Sirte\%20Summit\%20Decision\%200n\%20the\%20African\%20Union\%22 $>$ but has now been rendered defunct by the adoption of the Peace and Security Council Protocol.

(43) The Peace and Security Protocol, adopted in Durban, South Africa (July 2002), entered into force in December 2003; reproduced in C Heyns (ed), Compendium (see n 31 above) 13.

(44) Ibid.

(45) For the definition of 'collective human security' that inspired this insight, see T Farer in TG Weiss (ed) (n 4 above) 3, 155 .

(46) Ibid.

(47) See OC Okafor, Re-Defining Legitimate Statehood: International Law and State Fragmentation in Africa (The Hague: Martinus Nijhoff, 2000).

(48) Ibid, 136-7.

(49) Ibid.

(50) eg, see 'The Responsibility to Protect' (n 19 above) 15. 
(51) African Commission, Resolution on the Situation of Human Rights in Africa, 16th Ordinary Session (25 October-3 November 1994) reproduced in the African Commission on Peoples' Rights, Recommendations and Resolutions (see $\mathrm{n} 32$ above) 31.

(52) African Commission, Resolution on Rwanda, 16th Ordinary Session (25 October-3 November 1994), reproduced in the African Commission on Peoples' Rights, Recommendations and Resolutions (see n 32 above) 28.

(53) See also R Murray, Human Rights in Africa (n $\underline{27}$ above) 117.

(54) I Mgbeoji, Collective Insecurity (see $\mathrm{n} 4$ above) (in the title thereof).

(55) See n 52 above, 28.???

(56) Ibid, 5 .

(57) African Commission, Resolution on Anti-Personnel Landmines, 13th Ordinary Session (13-22 March 1995) reproduced in the African Commission on Peoples' Rights, 'Recommendations and Resolutions' (see n 32 above) 37.

(58) African Commission, Resolution on the Sudan, 17th Ordinary Session (13-22 March 1995) reproduced in the African Commission on Peoples' Rights, 'Recommendations and Resolutions' (see n 32 above) 32.

(59) Ibid, 4.

(60) $\underline{\text { Ibid, } 6 .}$

(61) African Commission, Resolution on the Situation in the Darfur Region of the Sudan, 37th Ordinary Session (27 April-11 May 2005, Eighteenth Annual Activity Report), http://www1.umn.edu/humanrts/africa/res-darfur37-2005.html $\rangle$.

(62) Ibid, ii.

(63) African Commission, Resolution on Liberia, 19th Ordinary Session (26 March-4 April 1996) reproduced in the African Commission on Peoples' Rights, 'Recommendations and Resolutions' (see n 32 above) 41.

(64) Ibid, 4 .

(65) Ibid, 6 .

(66) Ibid, 7 .

(67) African Commission, Resolution on South Africa, 15th Ordinary Session (18-27 April 1994) reproduced in the African Commission on Peoples' Rights, 'Recommendations and Resolutions' (see n 32 above) 24 . 
(68) African Commission, Resolution on the Sudan, 19th Ordinary Session (26 March-4 April 1996) reproduced in the African Commission on Peoples' Rights, 'Recommendations and Resolutions' (see n 32 above) 46.

(69) Ibid, 6.

(70) Katangese Peoples' Congress v Zaire, Communication No 75/92 (1996) 3 International Human Rights Reports 136.

(71) OC Okafor, 'Peacebuilding' (see n $\underline{27}$ above) 441-2.

(72) Katangese Peoples' Congress v Zaire (see $\mathrm{n} 70$ above) 1.

(73) Ibid, 6.

(74) OC Okafor (see n $\underline{27}$ above) 442.

(75) Social and Economic Rights Action Centre (SERAC) and another $v$ Nigeria, Communication No 155/96, decided in 2001). This case is also reproduced in C Heyns (ed),Compendium (see n 31 above) 159.

(76) Resolution on Rwanda (see n 52 above) 6.

(77) Eighteenth Activity Report of the African Commission on Human and Peoples' Rights, EX.CL/199 (VII) (on file with the author) 6.

(78) This was the Regional Sensitization Seminar on the Rights of Indigenous Populations/Communities in Africa, Yaounde, Cameroon (13-16 September 2006), http://www.achpr.org/english/news/Seminar en.htm $\rangle$.

(79) Ibid.

(으) See generally, J Oloka-Onyango, 'Beyond the Rhetoric: Reinvigorating the Struggle for Economic and Social Rights in Africa’ (1995) 26 California Western International Law Journal 1.

(81) C Heyns, 'The African Regional Human Rights System: The African Charter' (2004) 108 Pennsylvania State Law Review 679, 690-1.

(2) Social and Economic Rights Action Centre (SERAC) and another $v$ Nigeria (see $\mathrm{n} 75$ above).

(83) Purohit and Moore $v$ the Gambia, Communication No 241/2001, Sixteenth Annual Activity Report 2002-2003. This case is reproduced in C Heyns (ed), Compendium (see $\mathrm{n} 31$ above) 178 (hereinafter 'Purohit Case'). See also C Mbazira, 'The Right to Health and the Nature of Socio-Economic Rights Obligations under the African Charter: The Purohit Case' at: http://www.communitylawcentre.org.za/ser/esr2005/2005nov_charter.php $\rangle$.

(84) OC Okafor, The African Human Rights System, Activist Forces and International Institutions (see n $\underline{26}$ above) 269. 
(85) NJ Udombana, 'Social Rights are Human Rights: Actualizing the Rights to Work and Social Security in Africa' (2006) 39 Cornell International Law Journal 181, 235. See also Heyns (n 81 above) 691.

(므) Heyns, Ibid, 691.

(87) Social and Economic Rights Action Centre (SERAC) and another $v$ Nigeria (see $\mathrm{n} 75$ above) 50, 55, 59 , and 64.

(88) Ibid, 60 and 65 .

(89) Ibid.

(90) Purohit Case (see n $\underline{83}$ above) 44.

(91) Ibid, 84.

(92) Ibid, 83 .

(93) Between 13-17 September 2004, the Commission (and its NGO partners, namely: Interights, the Centre for Human Rights, University of Pretoria, and the Cairo Institute for Human Rights Studies) organized a seminar on ESC rights in Pretoria, South Africa. See S Khoza, 'Promoting the Realisation of Economic, Social and Cultural Rights: The African Commission holds a Seminar in Pretoria' (2004) 4 African Human Rights Law Journal 334. See also NJ Udombana (n 85 above) 181.

(94) African Commission, Resolution on Economic, Social and Cultural Rights, 36th Ordinary Session (27 November-3 December 2004), Eighteenth Annual Activity Report (on file with the author) 8 and Annex 1. See also: 〈http://www.achpr.org/english/resolutions/resolution78 en.html $\rangle$.

(95) Ibid, 3 .

(96) Pretoria Statement on Social, Economic and Cultural Rights in Africa (17 September 2004), ACHPR/Res.73 (XXXVI) 04.

(97) Resolution on Economic, Social and Cultural Rights (see n 94 above) 10 (of preamble).

(98) eg, see D Kennedy, 'A New World Order: Yesterday, Today and Tomorrow' (1994) 4 Transnational Law and Contemporary Problems 329, 339-57 and D Kennedy, 'The Move to Institutions' (1987) 8 Cardozo Law Review 841.

(99) OC Okafor, 'After Martyrdom: International Law, Sub-State Groups, and the Construction of Legitimate Statehood in Africa' (2000) 41 Harvard International Law Journal 503(hereinafter 'Martyrdom').

(100) Protocol to the African Charter on Human and Peoples' Rights on the Rights of Women, adopted 2003, reproduced in C Heyns (ed), Compendium (see n 31 above) 38.

(101) African Commission, 'Principles and Guidelines on the Right to a Fair Trial and Legal Assistance in Africa', 2003, reproduced in C Heyns (ed), Compendium (see n 31 above) 210. 
(102) C Heyns, 'The African Regional Human Rights System' (see n $\underline{81}$ above) 690-1. See also C Mbazira (n $\underline{8} 3$ above) 2.

(103) Ibid, 691.

(104) See generally, J Oloka-Onyango, 'Human Rights and Sustainable Development in Contemporary Africa: A New Dawn, or Retreating Horizons?' (2000) 6 Buffalo Human Rights Law Review 39, 70; AAR Mohamed, 'Article 58 of the African Charter on Human and Peoples' Rights-A Legal Analysis and How it Can be Put into More Practical Use' [1996] ASICL Proceedings 290; R Murray, 'Decisions of the African Commission on Individual Communications under the African Charter on Human and Peoples' Rights' (1997) 46 International and Comparative Studies Quarterly 412, 414; R Murray, 'On-Site Visits by the African Commission on Human and Peoples' Rights: A Case Study and Comparison with the InterAmerican Commission on Human Rights' (1999) 11 African Journal of International and Comparative Law 460, 463-4, and 473; S Gutto, ICJ Workshops on NGO Participation in the African Commission on Human and Peoples' Rights: A Critical Evaluation (Geneva: International Court of Justice, 1996), 14-16, and 'Non-Governmental Organizations, Peoples' Participation, and the African Commission on Human and Peoples' Rights: Emerging Challenges to Regional Protection of Human Rights' in B Andreassen and T Swineheart (eds),Human Rights in Developing Countries, 1991 Yearbook (Oslo: Scandinavian University Press, 1992), 40-2; U Essien, 'The African Commission: Eleven Years After' (2000) 6 Buffalo Human Rights Law Review 93, 94, and 97-9; UO Umozurike, The African Charter on Human and Peoples' Rights (The Hague: Martinus Nijhoff, 1997), 67-73; FD Gaer, 'First Fruits: Reporting by States under the African Charter on Human and Peoples' Rights' (1992) 10 Netherlands Quarterly on Human Rights 29, 29-31; F Korley, 'The Role of Human Rights Institutions in the Promotion and Protection of Human Rights in Africa: A Ghanaian Appraisal' (1998) 10 ASICL Proceedings 199, 200; F Butegwa, 'Using the African Charter on Human and Peoples' Rights to Secure Women's Access to Land in Africa' in RJ Cook (ed), Human Rights of Women: National and International Perspectives (Philadelphia, PA: University of Pennsylvania Press, 1994), 495, 504, and 506; and W Benedek, 'The African Charter and Commission on Human and Peoples' Rights: How to Make it More Effective' (1993) 11 Netherlands Quarterly of Human Rights 25, 28-32.

(105) J Oloka-Onyango, ibid, 70-1.

(106) See $\mathrm{n} \underline{26}$ above, 269.

(107) EA Ankumah (see n 27 above) 40.???

(108) OC Okafor (see nn $\underline{26}$ and $\underline{27}$ above).

(109) See n $\underline{80}$ above, 70 .

(110) NJ Udombana (see n $\underline{85}$ above) 233.

(111) See n $\underline{81}$ above, 691 .

PRINTED FROM OXFORD SCHOLARSHIP ONLINE (www.oxfordscholarship.com). (c) Copyright Oxford University Press, 2015. All Rights Reserved. Under the terms of the licence agreement, an individual user may print out a PDF of a single chapter of a monograph in OSO for personal use (for details see http://www.oxfordscholarship.com/page/privacy-policy). Subscriber: York University; date: 11 December 2015 